once again the much criticised 'tritubercular theory'. In this, he was supported by Mr. Hinton, of the Zoological Department of the British Museum. Prof. R. Goldschmidt (Berlin) gave an account of the progress of his long-continued researches on the genetics of local races of the gipsy moth, and came to the conclusion that local races do not represent a stage in the evolution of species. Prof. Przibram (Vienna) demonstrated living specimens of a stick insect in which transplanted legs were voluntarily movable, although sections of similar specimens failed to reveal any connexion with the central nervous system.

Dr. Calman directed attention to the centenary of Darwin's visit to the Galapagos Islands and to the action of the Government of Ecuador in declaring certain of the islands a Nature reserve. The Congress adopted a resolution expressing its appreciation of the step taken by the Ecuadorian Government and offering its co-operation in any further action that might be necessary to preserve from extinction the very interesting fauna of the islands.

Probably no section of the Congress worked harder than the members of the International Com. mission on Zoological Nomenclature who sat (mostly in their shirt-sleeves !) for several hours each day under the chairmanship of Dr. Jordan of Tring, striving to disentangle the complexities of the problems submitted to them. For the first time in many Congresses, they met without their indefatigable secretary, Dr. C. W. Stiles, of Washington, who was prevented by illness from travelling to Lisbon. The result of their labours was the addition to the official list of nomina conservanda of a considerable number of generic names, mostly of insects, that were threatened with displacement or transference by a strict application of the rule of priority.

Unfortunately, some of the rooms where the meetings were held proved defective in their acoustic qualities. In particular, the lofty hall used for the plenary sessions, being lined with polished marble, provided an excellent demonstration of the reflection of sound. Since each speaker used a language which was foreign to some eighty per cent of his audience, effective discussion was impossible except where an abstract of the paper had been supplied beforehand. It is to be hoped that at future Congresses an attempt will be made to print abstracts of all papers and to distribute them well in advance of the opening day, and perhaps even to supply the full text of the more important addresses.

Finally, mention should be made of the lavish hospitality shown to the Congress by the Portuguese Government, the Municipality and the University of Lisbon, and the Municipality of Sintra, as well as by the Portuguese zoologists themselves. Many northern zoologists, making acquaintance for the first time with the brilliant sunshine, the blue sea, and the subtropical vegetation of Portugal, will not soon forget the friendliness of their Portuguese colleagues.

\title{
International Meteorological Conference
}

\section{WARSAW MEeting}

$\mathrm{T}$ HE International Meteorological Conference is an assembly, which meets every six years, of the directors of meteorological services in all parts of the world. A meeting was due in 1935, and by invitation of Dr. J. Lugeon, director of the National Meteorological Service of Poland, it was held in the Palais Stasjic, Warsaw, on September 6-13 under the presidency of Prof. E. van Everdingen. The conference was formally opened by the President of the Republic of Poland on September 6, and an address of welcome was delivered by the Minister of Communications. Only directors can be members of the full conference, but much of the detailed work of organisation is carried out by commissions nominated for special subjects, and each commission is composed of those meteorologists who are most expert in the work of the commission. Meetings of nearly all the commissions were held either in Warsaw before and during the main conference, or in Danzig during the preceding week.

The work of the conference and commissions covers a very wide field--synoptic meteorology, investigation of the upper air, climatology, agricultural meteorology, maritime meteorology, terrestrial magnetism, bibliography, etc., with many ramifications of detail. Synoptic meteorology, including the taking of observations at agreed hours, their broadcasting in code, reception and plotting on charts, has required the building up of an international organisation of great complexity, which is of vital importance not only for daily weather forecasting, but also for avia- tion. The extension of regular long-distance flying, in particular, has had the result that pilots pass from one country to another, and need to consult a variety of different weather charts, not only for the general isobars and winds, but also for details such as the form and height of clouds, or the presence of fog, thunderstorms, etc. To avoid confusion, the observations must be made and coded in a uniform manner -for which purpose detailed instructions in the use of the codes have been drawn up for international use. It is equally important, however, that the weather reports should be entered on the weather charts of different countries, according to a general plan, so that the pilot knows at once exactly where to look for the particular information which he requires. This 'station model', as it is termed, has been the subject of very careful consideration at Warsaw by the Commission for Synoptic Weather Information, and a great measure of agreement has been arrived at as to the form which it should take.

Another subject studied by this commission also concerns the international language of meteorology, namely the symbols used to represent various meteorological phenomena. At Warsaw, several new symbols, especially one for drizzle, were added to this international language. Finally, among a number of minor improvements in the codes for weather reports must be signalised the beginning of the arrangements for the inter-continental exchange of weather information by wireless, with the view of preparing within a few hours daily weather 
charts for a hemisphere, if not for the whole world.

The great importance of weather in aviation necessitates close relations between meteorological services and the authorities in charge of air lines. To meet this need, the conference at Warsaw formed a new commission, the purpose of which is to keep in close touch with the requirements of aviation, and to maintain and develop as required the meteorological organisation necessary for this purpose.

Another aspect of synoptic meteorology to which reference must be made is the construction of detailed daily charts of the northern hemisphere, now being prepared by the Deutsche Seewarte with international co-operation for the whole period of the Polar Year 1932-33. As reported by the Polar Year Commission, the preparation of these charts is progressing, though difficulty is being experienced in obtaining data for some of the more remote parts of the northern hemisphere. When completed, these charts will be of the greatest value for studies in dynamical meteorology.

The tendency towards internationalisation has appeared also in the domain of climatology, in the form of an international 'alphabet' for the headings of columns. Thus the column, for example, for 'pressure' in a climatological table should bear the letter $P$, no matter what country issues the table. The Climatological Commission has also devised a standard form of table for the guidance of meteorological institutes. Months are designated I-XII, but both in climatology and in agricultural meteorology the need has been felt for the use of a unit of time shorter than a month and there has been great dis. cussion of the relative advantages of the 5-day period, or pentad, and the week, with the result that both units have received international approval.

The Commission for Terrestrial Magnetism and Atmospheric Electricity was occupied mainly with questions of detail. Among the resolutions were also appreciations of the action of the British Admiralty in deciding on the construction of a non-magnetic ship specially designed to carry on the researches formerly made on the ill-fated Carnegie, and of the Canadian authorities in transforming the temporary geophysical station erected at Chesterfield Inlet for the Polar Year into a permanent station.

The report of the Commission for Bibliography, which was unanimously adopted by the conference, presented a new plan of classification for meteorological literature, affiliated to the decimal classification of the International Institute of Bibliography, but thoroughly revised. This classification has been studied and discussed for several years, and its completion will greatly facilitate bibliographical work in meteorology.

The work of an international conference does not end with the formal debates and resolutions; there remain many problems which can only be resolved by private discussion among the members. The value of the Warsaw conference was greatly increased by the presence of delegates from all parts of the world. Africa was especially well represented, and the practical problems of organisation in that difficult continent were fully explored.

On Sunday, September 8, an all-day excursion was made to the new aerological and radiometeorological observatory at Jablonna, which owes its inception to Dr. Lugeon, and which promises to be of as great importance in studies of the ionosphere in Poland as is the station at Slough, in England. On the evening before the final meeting, H.E. the Minister of Communications entertained members and their wives to a State banquet, where all speakers reflected the spirit of optimism prevailing in meteorology to-day, which was the keynote of the whole conference. After the meeting, many of the delegates proceeded to Cracow and the Tatra Mountains on an excursion which was admirably organised and provided an experience not readily to be forgotten.

\section{Biochemistry in Relation to Therapeutics}

GIR FREDERICK GOWLAND HOPKINS delivered the inaugural sessional address at the opening of the ninety-fourth Session of the College of the Pharmaceutical Society on Wednesday, October 2. His address included a wide survey of the needs of pharmacy to-day and of the educational means for satisfying them, and led him to examine a problem as old as education itself, the problem of how far vocational training is compatible with true education in which a subject is studied for its own sake as an intellectual exercise. It has often been said that science can only be taught properly when it is taught as pure science without reference to its applications. This claim is justified to the extent that vocational needs must not make the teaching of science so one-sided that the student risks missing the intellectual stimulus which the great generalisations of science provide.

Teachers of applied scientific subjects will be grateful to the president of the Royal Society for his declaration that the skilful teacher of students whose ultimate aim is to apply science in practice, can illustrate general principles adequately while selecting facts and aspects which have a permanent vocational value. Indeed, for the encouragement of the average student, it is important that the reality of this permanent value should be part of his faith. Without it he can never be an enthusiast for his calling. The preference for vocational training may well be based on the Anglo-Saxon preference for action rather than thought and for practice rather than theory, but it is an attitude of mind having in it the seeds of certain dangers. Indeed, a distrust of theory has sometimes kept Great Britain from being in the van of intellectual and not less of commercial progress : "It was because it had become really scientific that the medical knowledge of another country received for a long period and up to the time of the War the greatest respect in the world and it was because its chemists were so fully trained in theory that the same country obtained among other similar advantages a long lead in the production of synthetic drugs which rightly or wrongly brought it enormous profits".

On the same occasion Sir Frederick Gowland Hopkins took occasion to review the present state of biochemistry; in particular, in its relation to 